\title{
ELEMEN-ELEMEN ARSITEKTUR JENGKI PADA EKSTERIOR BANGUNAN INDIS WISMA KILANG BALIKPAPAN
}

\author{
Hatta Musthafa Adham Putra \\ Staf Pengajar Prodi Arsitektut, Jurusan Desain, Politeknik Negeri Samarinda \\ E-mail: hattamusthafa@gmail.com
}

\begin{abstract}
Jengki's architecture has become part of the architectural history in indonesia. Not much an area that has a relic langgam this building. Balikpapan bombed by allies in 1945 , so not much dutch heritage that can still be seen now. One complex building with a style of jengki's architecture were still standing in the region complex wisma the refinery in land ofpertamina.

Kilang's guesthouse, now a day, better known as Kilang's Cafe .This building consisted of six unit building that consist of 2 ( two ) the floor which lined with the face toward the south. Distinctness of the exterior part kilang's guesthouse is the interface of jengki's architecture. Unique elements is evident from the form of a roof, the form of a wall, there is a porch / are permitted, the form of the sills of being modified, using of rooster , as well as decorative elements advocates building. As a building unique and stylized typical indis - jengki, then that is worth creation kilang's guesthouse cared for and preserved.
\end{abstract}

Keywords : jengki, indisch, kilang's guesthouse Balikpapan

\begin{abstract}
ABSTRAK
Arsitektur jengki telah menjadi bagian dari sejarah perkembangan arsitektural di Indonesia. Tidak banyak daerah yang memiliki peninggalan langgam bangunan ini. Balikpapan dibom oleh sekutu pada tahun 1945, sehingga tidak banyak peninggalan Belanda yang masih dapat dilihat saat ini. Salah satu komplek bangunan dengan gaya arsitektur Jengki masih berdiri di kawasan komplek wisma kilang di lahan Pertamina.

Wisma kilang, saat penelitian ini ditulis, lebih dikenal dengan sebutan wisma kilang. Bangunan ini terdiri dari 6 (enam) buah rumah 2 (dua) lantai yang berjejer dengan menghadap ke arah selatan. Keunikan dari bagian eksterior wisma kilang ini adalah tampilan arsitektur jengki. Elemen unik tersebut terlihat dari bentuk atap, bentuk dinding, ada/tidaknya beranda, bentuk kusen yang dimodifikasi, penggunaan rooster, serta elemen dekoratif pendukung bangunan. Sebagai bangunan unik dan bergaya khas indis - Jengki, maka sudah sepantasnya wisma kilang ini dirawat dan dilestarikan.
\end{abstract}

Kata kunci : Jengki, Indis, Wisma kilang balikpapan 


\section{PENDAHULUAN}

Arsitektur Jengki menjadi pelopor arsitektur di Indonesia pasca kemerdekaan dan berkembang pada tahun 1950-1960. Dalam rentang waktu yang singkat, arsitektur jengki muncul sebagai bentuk perlawanan (dalam bidang arsitektur) pada kolonialisme serta semangat pencarian jati diri arsitektur Indonesia. Sejarah Indonesia mencatat bagaimana Bung Karno pada tahun yang sama sedang gencar-gencarnya melakukan pembangunan, untuk menunjukkan jati diri bangsa Indonesia kepada dunia.

Istilah jengki banyak ditemui di tahun 1970-an, misalkan celana jengki, merujuk pada celana yang ketat dan sangat kecil bagian bawahnya. Juga sepeda jengki, serta perabot yang juga muncul di tahun 1970-an kita kenal dengan sebutan meja jengki. Istilah jengki banyak digunakan untuk menyebut gaya-gaya serta karakter yang tidak populer pada saat itu. Meminjam istilah sekarang, jengki dapat dirujuk pada istilah anti-mainstream.

Secara etimologis kata Jengki berasal dari kata Yankee, yaitu sebutan untuk orang-orang New England yang tinggal di Amerika Serikat bagian utara. Penamaan jengki juga berhubungan dengan tren busana celana jengki yang berkembang pada masa itu. Selain itu, gaya jengki juga terinspirasi dari film-film koboi Amerika yang beredar di Indonesia. Posisi koboi dengan kuda-kuda miring ketika bertarung seolah menjadi dasar yang melahirkan bentuk arsitektur jengki.

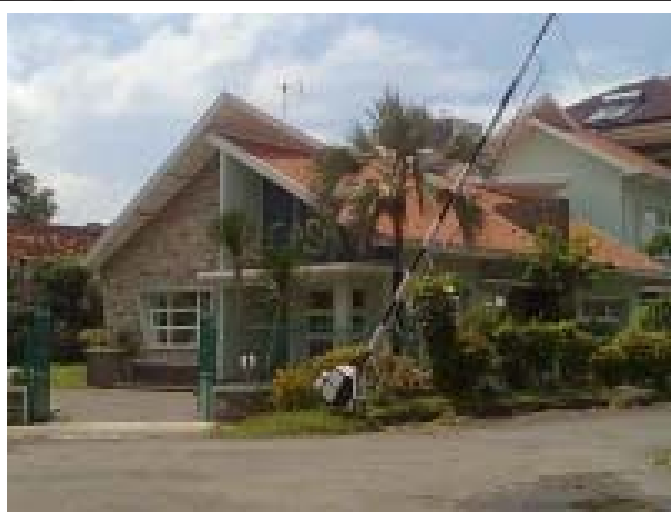

Gambar 1: contoh bentuk rumah jengki

Masih berhubungan dengan sejarah perkembangan arsitektur di Indonesia, ketika orang-orang Belanda pulang ke negerinya, para arsitekarsitek Belanda juga ikut kembali. Tinggal orang-orang Indonesia yang menjadi ahli bangunan dan asisten para arsitek Belanda. Sayangnya, arsitek generasi pertama ini belum memiliki pengetahuan akan arsitektur yang cukup kuat. Bahkan, kebanyakan langgam ini dipelopori oleh tukangtukang bangunan pada masa itu. Berkat peran merekalah, arsitektur jengki akhirnya lahir dengan bentuk yang unik.

Berbeda dengan rumah indis lainnya, arsitektur jengki memiliki ciri dan bentuk yang sama sekali berbeda. Seperti telah disebutkan di atas, arsitektur jengki lahir dari semangat penolakan kolonialisme. Apabila diperhatikan lebih dalam, sebenarnya bentuk arsitektur jengki dan kolonial jauh berbeda. Jika arsitektur kolonialisme didominasi bidang horisontal dan vertikal serta bentuk yang geometris, maka arsitektur jengki secara umum memiliki ciri unik dengan permainan bidang yang tidak simetris, garis-garis lengkung, serta jauh dari kesan kaku 
Hatta Musthafa Adham Putra, Elemen-elemen Arsitektur Jengki Pada Eksterior Bangunan Indis Wisma Kilang Balikpapan

Sayangnya, arsitektur jengki perlahan tapi pasti mulai punah keberadaannya. Padahal, rumahrumah jengki banyak kita temui di kota-kota besar bahkan sampai daerah pelosok sekalipun. Arsitektur jengki sendiri perlahan hilang tenggelam kalah dari tren arsitektur modernminimalis itu. Meskipun dibaliknya terdapat makna serta semangat yang besar, arsitektur jengki masih memiliki definisi yang bias, karena arsitektur ini dipelopori oleh arsitek angkatan pertama yang belum memiliki kemampuan arsitektur yang baik, sebagaimana dijelaskan di atas.

\section{Lokasi Wisma Kilang Komplek Pertamina Balikpapan}

Penelitian objek rumah jengki ini berlokasi di Jl. Jend. Sudirman, Wisma Pantai Kilang Mandiri, Balikpapan, Kalimantan Timur, Indonesia. Saat ini bangunan difungsikan sebagai bangunan komersil berupa kafe yang terbuka untuk umum pada jam tertentu. Kafe tersebut bernama wisma kilang, yang juga berfungsi di dalam ruangan maupun di luar ruangan (area pantai).

\section{METODE ANALISIS}

Berdasarkan teori karakter kawasan yang digunakan, maka penulis merumuskan variable penelitian ke dalam 6 (enam) elemen bentuk bangunan. Elemen bentuk bangunan terdiri dari bentuk atap, bentuk dinding, ada/tidaknya beranda, bentuk kusen yang dimodifikasi, penggunaan rooster, serta elemen dekoratif pendukung bangunan

\section{PEMBAHASAN}

Terdapat beberapa elemen arsitektur yang unik pada bangunan wisma kilang yang berdiri di lahan komplek Pertamina Balikpapan ini. Keseluruhan elemen tersebut memiliki fungsi yang sangat baik bagi bangunan tropis. Mulai dari antisipasi curah hujan yang cukup tinggi, hingga aliran udara yang dikondisikan mengalir masuk dan keluar dengan leluasa melalui jalusi maupun roster.

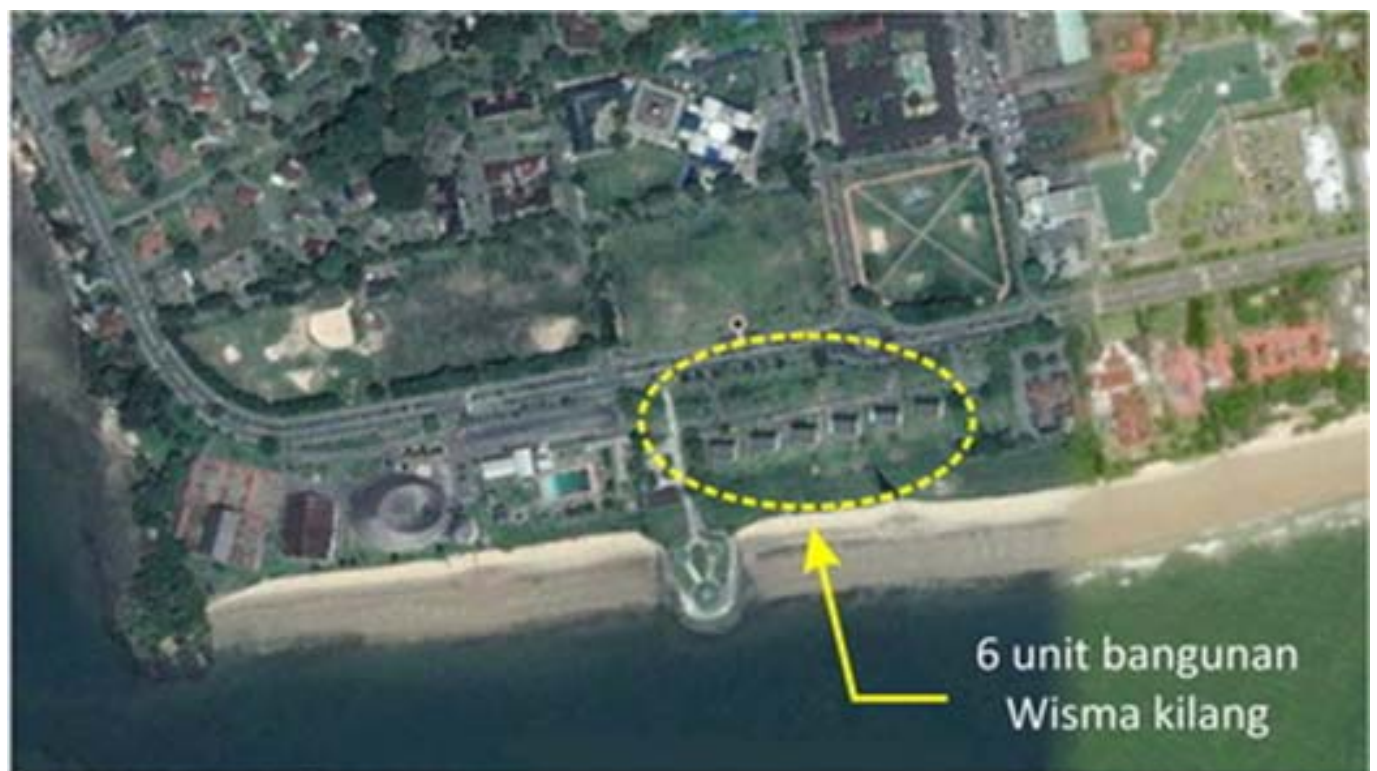

Gambar 2: Foto Udara Lokasi Wisma kilang Pertamina, Balikpapan 


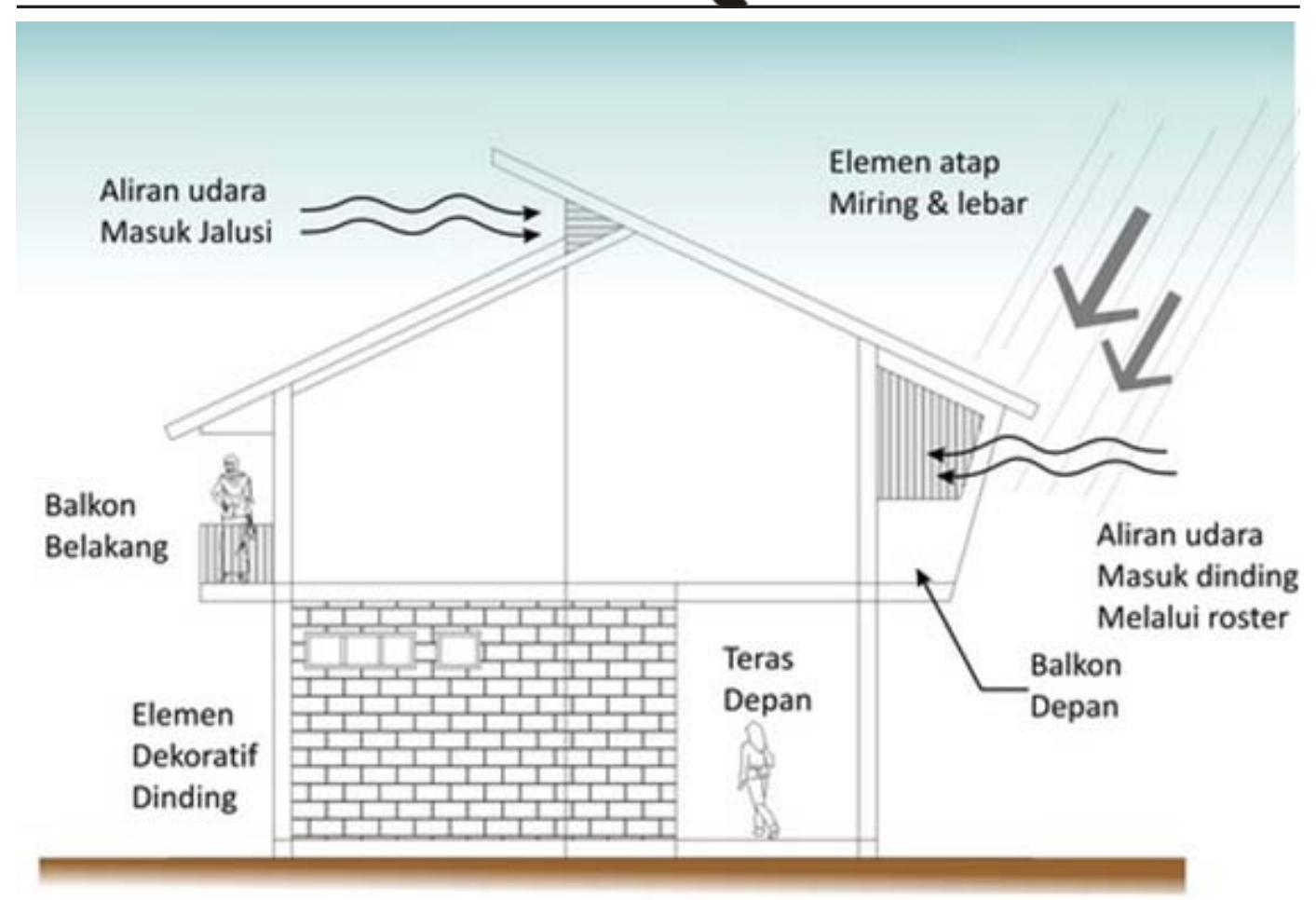

Gambar 3: Analisis elemen arsitektur jengki pada tampak samping wisma kilang

Sumber : Analisis Penulis, 2015

\subsection{Elemen Atap}

Atap pelana yang tidak lazim pada rumah jengki di wisma kilang Pertamina ini sangat khas dan standar. Persilangan atap dikarenakan adanya bagian dinding yang menjadi tempat udara masuk ke bagian atas plafond. Bentuk atap jengki ini merupakan bentuk umum, sehingga dari kejauhan sudah terlihat jelas gaya arsitektur yang digunakan pada bangunan ini.

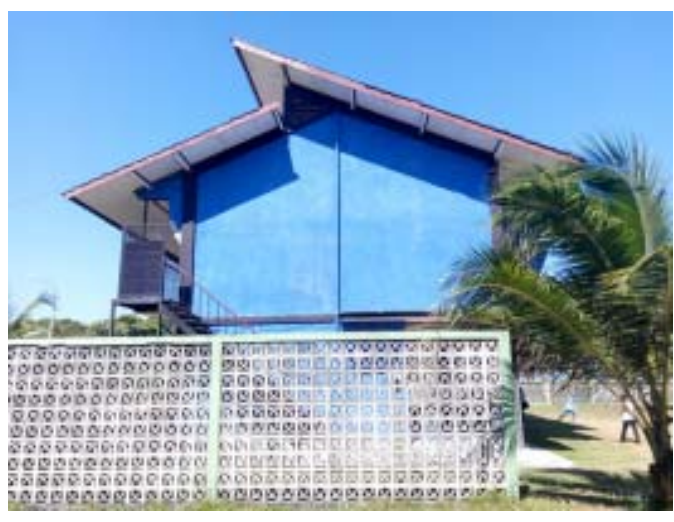

Gambar 4: Atap setengah pelana pada wisma kilang pertamina, Balikpapan Sumber: Dokumentasi penulis, Juni 2015 
Hatta Musthafa Adham Putra, Elemen-elemen Arsitektur Jengki Pada Eksterior Bangunan Indis Wisma Kilang Balikpapan

\subsection{Dinding yang Unik}

Dinding miring menjadi ciri khas selanjutnya pada bangunan arsitektur jengki di wisma Kilang Pertamina Balikpapan ini. Dinding miring ini terdapat pada bagian beranda atau balkon depan. Manfaat yang diperoleh dengan dinding miring ini adalah memperluas area tidak kena cahaya matahari.

Selain memiliki pengaruh positif terhadap cahaya panas matahari, dinding miring pada balkon juga menghindari bangunan dari air hujan. Terkadang hujan turun dengan sudut kemiringan tertentu, yang akan masuk ke dalam bangunan. Dengan dinding miring ini, maka atap bangunan dapat menutupi area lantai balkon lebih sempurna. Di samping itu, dinding miring ini juga dilengkapi dengan lubang-lubang seperti kisi-kisi yang mengalirkan udara dari samping bangunan.

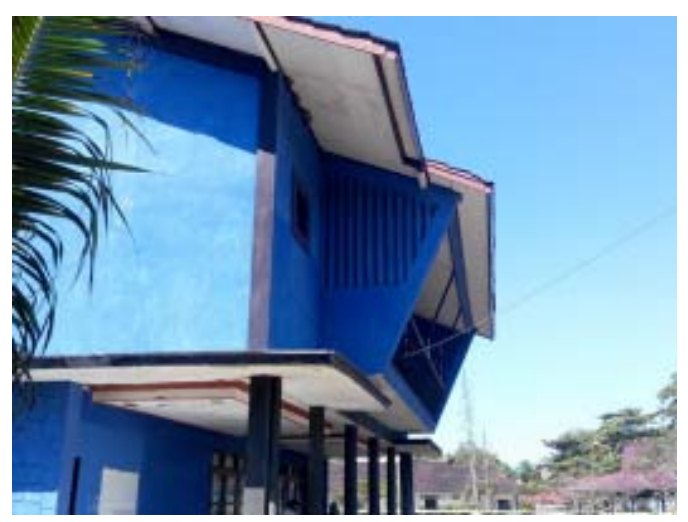

Gambar 5: Dinding miring wisma Kilang Balikpapan

Sumber: Dokumentasi penulis, Juni 2015

\subsection{Beranda Sebagai Ruang Perantara}

Beranda atau teras, terdapat di bagian bawah (lantai 1) dan lantai 2 bangunan. Teras berfungsi sebagai ruang penerima tamu, tempat berteduh, dan tak sedikit sebagai aksentuasi pintu masuk. Bandingkan dengan ukuran teras rumah-rumah sekarang yang semakin mengecil. Teras pada rumah jengki masik memiliki kesan yang luas dan selaras dengan pekarangan.

Balkon pada lantai dua, terdapat di area depan dan belakang bangunan. Balkon bagian depan difungsikan untuk area sosialisasi antar penghuni wisma. Sementara balkon bagian belakang lebih sempit, cukup untuk sebagai selasar saja.

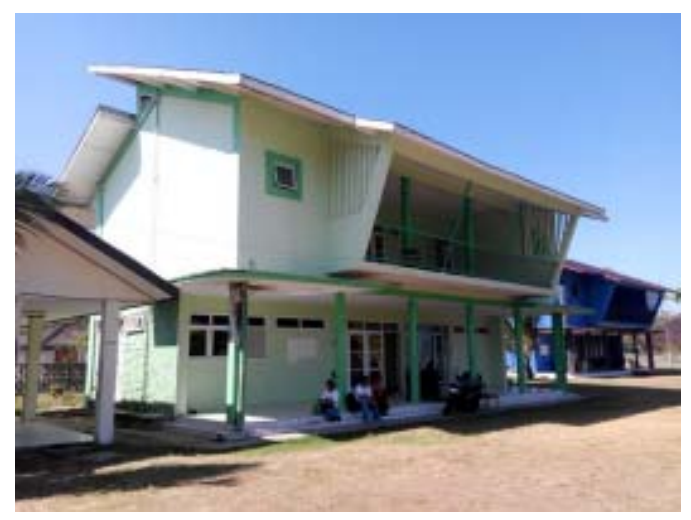

Gambar 6: Teras bawah dan Balkon atas di wisma kilang Pertamina, Balikpapan

Sumber: Dokumentasi penulis, Juni 2015 


\subsection{Modifikasi Bentuk Kusen dan Perletakan Jendela.}

Bentuk kusen unik dijumpai di bagian sisi timur dan sisi barat bangunan. Bentuk unik tersebut dilihat berupa jendela yang menjorok ke sisi luar bangunan. Jendela ini adalah satusatunya jendela pada sisi timur dan barat, di mana sinar matahari menyinari bangunan dengan lebih optimal.

Kusen yang unik ini bertujuan untuk mendapatkan cahaya matahari tambahan jika diperlukan. Bentuknya yang menjorok ke luar, membuat panas matahari yang masuk tidak langsung ke dalam ruangan, namun hanya sebatas dinding ruangan tersebut.

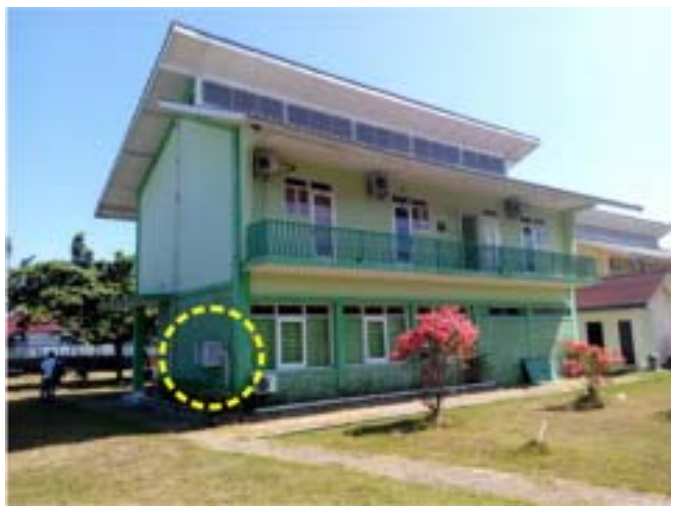

Gambar 7: Modifikasi jendela (lihat lingkaran), sebagai sarana masuknya cahaya

Sumber: Dokumentasi penulis, Juni 2015

\subsection{Kerawang atau Rooster}

Penggunaan kerawang atau rooster merupakan penyesuaian terhadap iklim tropis. Bentuk lain dari kerawang adalah berupa jalusi, yaitu kisi-kisi seperti jendela yang memiliki sudut miring sehingga cahaya masuk dengan minim, namun aliran udara mengalir dengan optimal. Fungsi utamanya adalah sebagai ventilasi untuk pergantian udara secara alami. Selain itu dengan bermacam-macam bentuk dari segilima, segitiga, lingkaran, hingga trapesium tak beraturan menjadi ekspresi estetika pada rumah jengki.

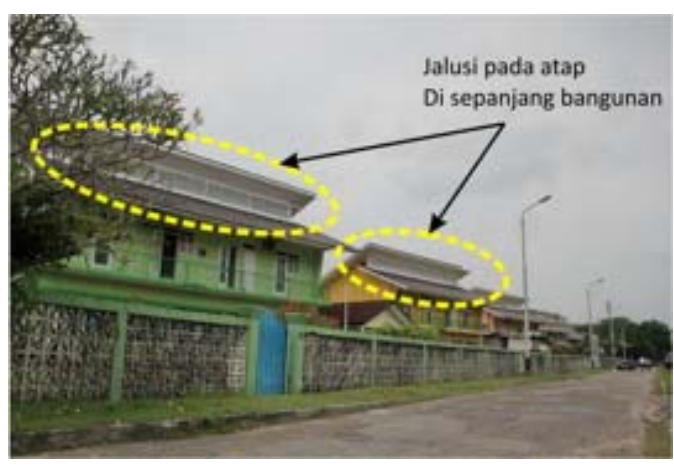

Gambar 8: Jalusi (kisi-kisi) pada atap, sebagai jalur angin masuk ke atas rumah

Sumber: Dokumentasi penulis, Juni 2015

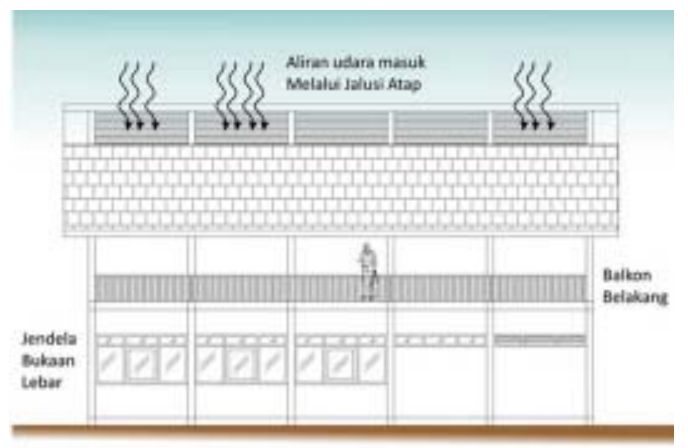

Gambar 9: Analisis elemen arsitektur jengki pada tampak belakang, wisma kilang

Sumber: Analisis Penulis, 2015 
Hatta Musthafa Adham Putra, Elemen-elemen Arsitektur Jengki Pada Eksterior Bangunan Indis Wisma Kilang Balikpapan

Sebenarnya fungsi utama dari karawang adalah sebagai anginan. Lancarnya sirkulasi di dalam setiap ruang pada rumah tinggal merupakan fungsi yang utama. Namun, pada arsitektur jengki fungsi ini berlanjut dengan hadirnya kreativitas. Penggunaan karawang tidak lagi dipahami sebagai sebuah fungsi, tetapi juga merupakan bagian dari wahana untuk menghadirkan estetika baru.

\subsection{Elemen Dekoratif pada Tampak Bangunan.}

Elemen-elemen dekoratif merupakan ungkapan para penghuni serta kreatifitas para arsitek jengki. Maka kita menemukan satu ciri dekorasi yang sama antara satu rumah jengki dengan yang lain. Ragam dekoratif kreasi arsitek jengki kebanyakan kombinasi-kombinasi garis lengkung dengan motif alam, ataupun pola-pola garis vertikal dan horisontal. Elemen ini dapat kita lihat pada dinding atau pada kolom bangunan.

Pada bangunan wisma kilang ini, elemen batu alam ditemui pada sisi samping bangunan. Motifnya tidak beraturan namun mengisi sisi kosong pada dinding samping.

\section{Kesimpulan dan Saran}

Arsitektur jengki perlahan tapi pasti mulai punah keberadaannya, kalah dari tren arsitektur modernminimalis yang banyak dibangun saat ini. Tidak banyak bangunan arsitektur jengki yang masih bertahan. Khusus untuk kota Balikpapan, bangunan asli peninggalan Belanda pada saat ini yang masih dapat dinikmati adalah di Wisma kilang yang berdiri di lahan milik Pertamina ini. Selayaknya bangunan ini dilestarikan dan menjadi pembelajaran bagi perkembangan arsitektur Kota Balikpapan. diharapkan peran serta pemerintah kota, maupun pemerintah pusat, untuk segera menetapkan bangunan arsitektur jengki ini ke dalam cagar budaya.

Perlu adanya campur tangan

pemerintah dalam mengelola aset bangunan arsitektur jengki ini, dikarenakan fungsi bangunan saat ini adalah kafe. Fungsi komersil sebagai kafe ini tidak mendukung upaya revitalisasi bangunan. 


\section{DAFTAR PUSTAKA}

Ardhiati, Y. (2005). Bung Karno Sang Arsitek : Kajian Artistik Karya Arsitektur,Tata Ruang kota, Interior, Kria, Simbol, Mode Busana dan Teks Pidato 1926-1965. Depok : Komunitas Bambu

Dyah, A. (2000). Tipologi Perubahan Wajah Bangunan Rumah Jengki di Kawasan Pakubuwono Jakarta Selatan. Jurnal Teknik Arsitektur Universitas Budi Luhur.

Kurniawan, K. R. (1999). Identifikasi Tipologi dan Bentuk Arsitektur Jengki di Indonesia Melalui Kajian Sejarah. Jurnal Teknik Arsitektur Universitas Indonesia. Laporan Penelitian SPP/DPP

Matanasi, Petrik. (2015). Balikpapan Tempo Doeloe. Penerbit SiBuku. Yogyakarta

Widayat, Rahmanu. (2006). spirit dari rumah gaya jengki ulasan tentang bentuk, estetika, dan makna. Jurnal Desain Interior UNS Surakarta

Balikpapanguide.com 